the Association be so fortunate as to collect / man of the most unblemished character; a fund for the distressed members, the against the breath of calumny be should be claimants will be marvellously few.

The prospectus does not mention the names of the projectors and the present committee (except the highly respectable president); is it expected that the general practitioners will pledge themselves to men unknown? The committee should be selected from men of unimpeachable integrity, irreproachable character, and great influence in society. Many useful measures have been lost by neglecting these particulars, and permitting the interference of men of no character, or of bad character, or of questionable character, or of men who, whatever their moral worth, were too obscure to command the respect and attention of those to whom they were unknown. The committee of the "Association" may be men every way eligible, but until we know who they are, they are not entitled to our alliance. Their meetings and proceedings ought to be open and public, and then they must be above suspicion. I am, Sir, Yours respectfully, A General Practitioner.

\title{
ROYAL WESTERN HOSPITAL.
}

DR. AYRE.

THE following is the letter referred to in Dr. Ayre's communication of last week:-

\section{To W. N. Beechey, Esq.}

Dear Sir,-It is with feelings much wounded that $I$ now address you. 'The subject of the two last special meetings of the Western Hospital, has received my most serious deliberation, and the result compels me to beg you will tender my resignation as one of the committee, to my brother managers of the Western Hospital.

In taking this step, I feel the necessity of entering into some explanation, in which I will be as brief as possible. The charges, in the first place, brought by Mr. Sleigh against Mr. Truman, were, according ito my opinion, refuted by the latter gentleman most completely. Not only, therefore, do I consider Mr. Truman blameless, but I feel that we are indebted to him for having ascertained what the real state of the establishment is, in lieu of the garbled statements that have from time to time been exhibited. My next view of the proceedings is, that the charges brought against Mr. Sleigh are completely substantiutea by the evidence of Dr. Ayre and Mr. Truman. To these gentiemen, therefore, I individually feel the greatest obligation for their spirited and independent copduct. The situation of surgeon to an hospital should be held by a

proof ; amongst the profession he should (I will go the length to say) be belored, upon the principle that subscribers would gene. rally appeal to their medical advisers previously to supporting an establishment which, from its recent formation, depends for its fame upon the medical officers; if it were necessary, by way of confirmation, I would quote what Sir Charles Scudamore said. With an opinion thus formed, after the withdrawal of the medical officers, I at once suggested our recommending $\mathrm{Mr}_{\text {, }}$ Sleigh to resign, most fully bearing in mind Sir Charles Scudamore's parting injunction, of considering the welfare and prosperity of the hospital, instead of this or that indiri. dual ; as these my sēntiments were not con. curred in, of course the suggestion fell to the ground.

A gain, I cannot regard the serrices of Mr. Sleigh in the same light as most of the committee. So far from their being vall. able to the establishment, I pronounce then to be most inimical to it; but for the on. warrantable outlay made by that gentleman (to suit his own private ends, and by him admitted), public charity and benevolence would have met the objects for which the institution was formed; and in lieu of your committee being threatened with actions br a body of creditors, they would have had the pleasing satisfaction of making a favour. able report at the ensuing annual meeting; and when once established, by that I meat firmly, and the funds increasing, Mr. Sleigh, on appealing to that Committee of management, would have received from it every assistance, in his desire of forming a school. His too hasty conduct lass, I fear, ruined an establishment which was calcu: lated to have relieved suffering humanity to an extent which, sanguine as I was at one time, might far have exceeded my ideas.

With these sentiments, you will see the impossibility of my setting at the same board with gentlemen with whom in opinion I so differ, but at the same time respect most highly. May every success attend them in so excellent a cause, is the prayer of, dear Sir,

Yours very sincerely, (Signed) A. P. Jomnsox."

Lloyd's Coffee House, Jec. 3rd, 1829.

MR. SLEIGH.

\section{To the Editor of $\mathrm{THE}$ Larcer.}

Sir,-I beg once more to trouble por, not that I consider Dr. Ayre's letter re* quires a reply, or that he himself is worthy the notice of any man, "his tongue 